\title{
Detection of rabies virus nucleoprotein-RNA in several organs outside the Central Nervous System in naturally-infected vampire bats ${ }^{1}$
}

\author{
Luiz F. P. Vieira ${ }^{2 *}$, Sílvia R.F.G. Pereira², Aline C. Galante², Juliana G. Castilho ${ }^{3}$, \\ Rafael N. Oliveira ${ }^{3}$, Paulo E. Brandão ${ }^{4}$ and Ivanete Kotait ${ }^{3}$
}

\begin{abstract}
Vieira L.F.P., Pereira S.R.F.G., Galante A.C., Castilho J.G., Oliveira R.N., Brandão P.E. \& Kotait I. 2011. Detection of rabies virus nucleoprotein-RNA in several organs outside the central nervous system in naturally-infected vampire bats. Pesquisa Veterinária Brasileira 31(10):922-925. Setor de Virologia e Viroses, Laboratório de Sanidade Animal, Hospital Veterinário, Centro de Ciências e Tecnologias Agropecuárias, Universidade Estadual do Norte Fluminense, Av. Alberto Lamego 2000, Parque Califórnia, Campos dos Goytacazes, RJ 28013-602, Brazil. E-mail: luizuenf@yahoo.com.br

Rabies is a neurological disease, but the rabies virus spread to several organs outside the central nervous system (CNS). The rabies virus antigen or RNA has been identified from the salivary glands, the lungs, the kidneys, the heart and the liver. This work aimed to identify the presence of the rabies virus in non-neuronal organs from naturally-infected vampire bats and to study the rabies virus in the salivary glands of healthy vampire bats. Out of the five bats that were positive for rabies in the CNS, by fluorescent antibody test (FAT), viral isolation in N2A cells and reverse transcription - polymerase chain reaction (RT-PCR), $100 \%(5 / 5)$ were positive for rabies in samples of the tongue and the heart, $80 \%(4 / 5)$ in the kidneys, $40 \%(2 / 5)$ in samples of the salivary glands and the lungs, and $20 \%(1 / 5)$ in the liver by RT-PCR test. All the nine bats that were negative for rabies in the CNS, by FAT, viral isolation and RT-PCR were negative for rabies in the salivary glands by RT-PCR test. Possible consequences for rabies epidemiology and pathogenesis are discussed in this work.
\end{abstract}

INDEX TERMS: Lyssavirus, Desmodus rotundus, non-neuronal organs, rabies.

RESUMO.- [Detecção de núcleoproteína-RNA do vírus rábico em diversos órgãos fora do sistema nervoso central de morcegos hematófagos infectados naturalmente.] A raiva é uma doença neurológica, mas o vírus da raiva se dispersa para diversos órgãos fora do sistema nervoso central (SNC). Antígeno ou RNA do vírus da raiva

\footnotetext{
${ }^{1}$ Received on May 7, 2011.

Accepted for publication on August 2, 2011.

${ }^{2}$ Setor de Virologia e Viroses, Laboratório de Sanidade Animal (LSA), Hospital Veterinário, Centro de Ciências e Tecnologias Agropecuárias (CCTA), Universidade Estadual do Norte Fluminense (UENF), Av. Alberto Lamego 2000, Parque Califórnia, Campos dos Goytacazes, RJ 28013-602, Brazil. *Corresponding author: luizuenf@yahoo.com.br

${ }^{3}$ Instituto Pasteur, Avenida Paulista 393, Cerqueira César, São Paulo, SP 01311-000, Brazil.

${ }^{4}$ Departamento de Medicina Veterinária Preventiva e Saúde Animal, Faculdade de Medicina Veterinária e Zootecnia, Universidade de São Paulo (USP), Av. Prof. Dr. Orlando Marques de Paiva 87, Cidade Universitária, São Paulo, SP 05508-000.
}

já foram detectados em vários órgãos, tais como glândula salivar, pulmão, rim, coração e fígado. 0 presente trabalho teve como objetivo identificar a presença do vírus da raiva em órgãos não neuronais de morcegos hematófagos infectados naturalmente, e pesquisar a presença do vírus na glândula salivar de morcegos hematófagos sadios. Dos cinco morcegos positivos para a raiva no SNC pelas técnicas de imunofluorescência direta e isolamento viral em células N2A, $100 \%(5 / 5)$ foram positivos para a raiva nas amostras de língua e coração, 80\% (4/5) no rim, 40\% $(2 / 5)$ nas amostras de glândula salivar e pulmão, e $20 \%$ $(4 / 5)$ no fígado pela técnica de RT-PCR. Todos os nove morcegos negativos no SNC, pela imunofluorescência e isolamento viral, foram negativos na glândula salivar pela RT-PCR. Possíveis consequências para a epidemiologia e patogênese da raiva são discutidas.

TERMOS DE INDEXAÇÃO: Lyssavirus, Desmodus rotundus, órgãos não neuronais, raiva. 


\section{INTRODUCTION}

The rabies virus (Rhabdoviridae family and Lyssavirus genus) is known as a highly neurotropic and lethal pathogen of mammals. The rabies virus glycoprotein binds most effectively to cells of neuronal origin, reflecting the neurotropism of the rabies virus (Superti et al. 1984); nevertheless, the rabies virus has been isolated from several tissues from both experimentally- and naturally-infected animals (Charlton et al. 1984, Alves et al. 2003).

Briefly, the pathogenesis of rabies is the following: the virus gets into the body by the bite of a rabid animal, reaching the striated muscle and the connective tissue. In the muscle cells there occurs a viral amplification before the virus gets into the peripheral nerves. The neuronal infection and the centripetal, passive movement of the viral ribonucleocapsid complex in the axons deliver the virus to the central nervous system (CNS), usually via the spinal cord. The virus then spreads in the CNS, and the clinical signs appear. Next the virus moves centrifugally from the CNS through peripheral nerves to a number of organs: the adrenal cortex, the pancreas, the liver, the lungs, the heart and, most importantly, the salivary glands, the excretion site of the virus. Finally, the clinical picture culminates with depression, coma and death (Lyles \& Rupprecht 2007). The rabies virus can also get into the body by the mucosal route (Ramsden \& Johnston 1975, Orciari et al. 2001).

Historically speaking, in Brazil dogs have been the major transmitter of rabies to humans. However, in 2004 and 2005, 64 human deaths by rabies transmitted by hematophagous bats were reported (SVS 2008). On the other hand, approximately 3,200 cases of rabies in herbivores are reported annually in Brazil (MAPA 2007), but it is believed that the number of infected herbivores is ten times higher.

Given the importance of the vampire bat (Desmodus rotundus) in the transmission of rabies to humans and animals in Brazil, it is necessary to carry out further investigations on the interaction of rabies virus and vampire bats. The rabies virus infection in the CNS has been widely studied in several animal models; however, the role of the infection of other organs outside the CNS is poorly understood.

This work aimed to identify the presence of rabies virus in non-neuronal organs/tissues from naturally-infected vampire bats that were positive for rabies in the CNS, and to diagnose the rabies virus in the salivary glands of vampire bats negative for rabies in the CNS.

\section{MATERIALS AND METHODS}

Animals. Fourteen vampire bats (Desmodus rotundus) were captured during July of 2006, in the town of Quissamã, Rio de Janeiro State, Brazil (geographical position: S $22^{\circ} 05^{\prime} 15.7^{\prime \prime}$, W $041^{\circ}$ $\left.41^{\prime} 20.2^{\prime \prime}\right)$. The D. rotundus bats were captured with mist nets placed in front of a diurnal shelter. These bats were identified with number from 1 to 14 , used along this article. Bat no. 5 died during capture, the other bats were kept in captivity for two months. All bats were kept in the same cage. Bats were fed $20 \mathrm{ml}$ of defibrinated blood taken from healthy cattle daily.

In two months nearly all bats were sick and died, except for bats $\mathrm{n}^{\mathrm{o}} 12,13$ and 14 . Bats no. 3 and 4 showed incoordination and inability to fly. Apparently no increased aggressiveness was observed in these bats; however, an intense vocalization was noticed. The other bats that died ( $\mathrm{n}-1,2,5,6,7,8,9,10$ and 11) showed only prostration before death. The surviving Chiropterans (bats $\mathrm{n} \times 12,13$ and 14) were euthanized by inhalation of ether, and all bats were taken to Instituto Pasteur in São Paulo under refrigeration.

This work complies with Protocol no 74 issued by the Ethics Committee of the Universidade Estadual do Norte Fluminense Darcy Ribeiro.

Fluorescent antibody test (FAT) and viral isolation in N2A Cells. The whole encephalon of the bats were sampled and stored at $-20^{\circ} \mathrm{C}$ until an analysis was performed. Two techniques were used in the screening of the rabies virus: FAT, described by Dean et al. (1996) and viral isolation in murine neuroblastoma cell (N2A), described by Webster and Casey (1996).

Reverse transcription-polymerase chain reaction (RT-PCR) and DNA sequencing. Total RNA was extracted from tissue samples with TRIzol $^{\circledR}$ reagent (Invitrogen ${ }^{\mathrm{TM}}$ ) according to manufacturer's instructions. Reference strain (Challenge Virus Standard - CVS) and ultra-pure water were used as positive and negative controls respectively.

The brain, the salivary glands, tongue, heart, lungs, liver and kidneys from rabies-positive vampire bats were sampled and submitted to RT-PCR. The brain and the salivary glands from rabies-negative vampire bats, diagnosed by FAT and viral isolation, were also sampled and submitted to RT-PCR.

RT-PCR was performed as described by Orciari et al. (2001), with minor changes. To diagnose rabies a pair of primers $504 / 304$ was used. In the sequencing of the nucleoprotein gene, a pair of primers $21 \mathrm{G} / 304$ was used. The primers are as follows: sense-504 primer (5'-TATACTCGAATCATGATGAATGGAGGTCGACT-3'), position 1286-1317 of viral genome; antisense-304 primer (5'-TTGACGAAGATCTTGCTCAT-3'), position 1514-1533; and sense-21G primer (5'-ATGTAACACCTCTACAATG-3'), position 55-73 of viral genome.

The PCR products were sequencing as previously described (Carnieli Jr. et al., 2006). Sequencing reaction has been achieved with BigDye ${ }^{\circledR}$ Terminator v3.1 Cycle Sequencing Kit (Applyed Biosystems $^{\mathrm{TM}}$ ) and then purified with Sephadex ${ }^{\mathrm{TM}}$ G-50 (GE Healthcare), at last the sequences were then resolved on an ABI PRISM ${ }^{\circledR}$ 3100 Genetic Analyzer (Applied Biosystems ${ }^{\mathrm{TM}}$ ).

\section{RESULTS}

Out of the total of fourteen brains analyzed, five (35.7\%) were positive to rabies by FAT, viral isolation in N2A cell and RT-PCR. Table 1 shows the results of RT-PCR to rabies virus investigation in non-neuronal organs of these five positive bats. In short, rabies virus was detected in $100 \%$ $(5 / 5)$ of the tongue and heart, $80 \%(4 / 5)$ of kidneys, $40 \%$ $(2 / 5)$ of the salivary glands and lungs, and $20 \%(1 / 5)$ of liver.

The nine samples of the brain and the salivary glands from rabies-negative bats (bats no 6 to 14), by FAT and virus isolation in N2A cell, were tested by RT-PCR and all samples were negative.

The five nucleotide sequences of nucleoprotein genes were identical. These sequences were submitted to BLASTn (www.ncbi.nlm.nih.gov/BLAST) and showed a high identity with nucleoprotein gene sequences of rabies virus from Desmodus rotundus. 
Table 1. Results of RT-PCR to rabies virus nucleoprotein gene from several organs of vampire bats, positive to rabies in CNS by FAT and viral isolation in N2A cells

\begin{tabular}{ccccccc}
\hline Bat & Salivary gland & Tongue & Heart & Lung & Kidney & Liver \\
\hline 1 & + & + & + & - & + & - \\
2 & - & + & + & + & + & + \\
3 & - & + & + & + & - & - \\
4 & + & + & + & - & + & - \\
5 & - & + & + & - & + & - \\
\hline
\end{tabular}

\section{DISCUSSION}

The rabies virus is neurotropic, but it spreads to several organs other than the CNS. The most common form of the pathogenesis of rabies virus is, briefly, as follows: the virus enters the body by infected saliva in the muscular tissue. From the muscular tissue the virus goes to the peripheral nerves by neuromuscular junctions. Then, the rabies virus spreads within axons by retrograde axonal transport and infects the CNS. After the infection of CNS the virus spread to several organs, including the salivary glands. When the salivary glands are infected, the rabies virus goes to the saliva and the saliva carries the virus that can infect other animals (Jackson 2006). However, previous reports regarding the pattern of rabies virus distribution within body organs and pathologic features of peripheral organs during infection are limited (Hsu et al. 2005).

The viral RNA is detected in high concentration in hearth samples of vampire bats naturally infected (Carneiro et al. 2010). Despite the heart is often infected by the virus, it does not seem to be important for the spread of the virus, since the infection is confined to nerve fibers, but does not reach the cardiac muscle cells in foxes (Debbie \& Trimarchi 1970) and humans (Jogai et al. 2002).

In the early studies on rabies in bats Constantine et al. (1962) reported that terrestrial animals were infected with the rabies virus by the non-bite route when placed in bat-inhabiting caves. In the same cave that Constantine carried out his experiment, Winkler (1968) isolated the rabies virus from samples of air.

The airborne transmission could occur by the shedding of virus by the respiratory or urinary system. The kidneys, found positive to rabies virus in 4 out of 5 CNS-positive bats in the present study, could be a release door to the rabies virus.

Debbie \& Trimarchi (1970) showed the presence of rabies virus within tubular cells of the kidneys. The same authors reported that mice inoculated with urine from a rabid fox died of rabies.

It is thus possible that the urine forms aerosols that infect the bats and other animals inhabiting caves. Johnson et al. (2006) and Davis et al. (2007) reported that mice died of rabies as a result of aerosol exposure and intranasal inoculation. Bats did not succumb to rabies. On the other hand, an increased level of antibodies against rabies virus was found in bats after aerosol exposure (Davis et al. 2007).

Another physiological system that could shed the rabies virus is the respiratory system. In the present work rabies virus nucleoprotein RNAs in lungs of two bats have been detected. However, the lungs apparently do not play a role in the excretion of virus because the virus infects mainly the nervous fiber in the lungs, but not the lung epithelium (Bourhy et al. 1992). On the other hand, the rabies virus can be excreted in nasal secretion, as it was isolated in the nasal epithelium of bats (Constantine et al. 1973) and skunks (Charlton et al. 1984).

Among the five bats positive for rabies included in this study, only two had the rabies virus found in the salivary glands. As the saliva is the release site of the virus, it was expected to find the rabies virus in the salivary glands of all or almost all positive bats. This could vary, however, due to different times of virus progression from the CNS to the salivary glands and different incubation periods (Aguilar-Setien et al. 2005). In this study four out of the five positive bats died naturally, which brought the viral spread to an end.

All bats that were positive for rabies in the CNS, in the present work, were also positive for rabies in the tongue. Interestingly enough, in humans the rabies antigen is found more often in the tongue than in the salivary glands. It is possible that the virus reached the saliva through the tongue, since the rabies virus infects serous glandular cells and covers epithelial cells including taste cells (Li et al. 1995). On the other hand, Scheffer et al. (2007) reported that in virus investigation in the different tissues and organs of bats, the brain and salivary glands were, respectively, the most suitable sites for virus isolation. Carneiro et al. (2010) reported high rabies virus RNA concentration in tongue, however they analyzed tongue together with salivary gland, therefore cannot be compared their results with data from this work in tongue and salivary gland case.

It is reported the presence of classical and rabies-related virus in organs outside the CNS, either by the presence of viral genetic material or viral isolation in N2a cells and mouse inoculation (Echevarría et al. 2001, Jogai et al. 2002, Brookes et al. 2007, Scheffer et al. 2007). The organs where the rabies virus spread differ among the viral variants (Germano et al. 1988). So it is possible that the viral samples from the present work had a preference to infect the tongue instead of the salivary gland.

According to classical studies on the pathogenesis of rabies virus, the virus spreads in the centripetal direction, i.e., it first infects the brain and then the various organs of the body (Jackson 2006). However, Echevarría et al. (2001) and Aguilar-Setien et al. (2005) detected, respectively, rabies-related and classical-rabies virus in the saliva of bats that did not show viral infection in the brain.

The bats in the experiment by Aguilar-Setien et al. (2005) that survived inoculation were kept living for two years. During this time, the virus could be recovered in the saliva of these bats only once - between the first and third week after inoculation.

The results from the present investigation did not show rabies virus in the salivary glands from healthy bats. This may suggest that, for these viral samples, either the salivary glands are always infected after brain infection or the 
time the virus was present in the salivary glands did not match the time of the diagnosis.

A more comprehensive knowledge about the non-neuronal infection by rabies virus is critical not only for studies of the disease's pathogenesis, but also to diagnose it. The detection of the rabies virus in non-neuronal sites may serve as a useful tool in the ante-mortem diagnosis (Jogai et al. 2002). Tests are performed on samples of saliva, serum, spinal fluid, and skin biopsies of hair follicles from the nape of the bat's neck. Saliva can be tested by virus isolation or RT-PCR (Madhusudana \& Sukumaran 2008).

The preliminary results presented in this work show that the transmission of rabies via saliva of $D$. rotundus might not correlate directly to rabies pathogenesis in the salivary glands. It is possible that the tongue is the major site of virus shedding. Continued studies of viral titers and antigen distribution might bring further insights on the major site of virus shedding in $D$. rotundus and the importance of other minor sites of virus excretion.

Acknowledgements.- To Instituto Pasteur, São Paulo, for their excellent technical assistance and for the availability of their Laboratory of Molecular Biology. We wish to thank CNPq and FAPERJ for the financial support of this research.

\section{REFERENCES}

Aguilar-Setien A., Loza-Rubio E., Salas-Rojas M., Brisseau N., Cliquet F., Pastoret P.P., Rojas-Dotor S., Tesoro E. \& Kretschmer R. 2005. Salivary excretion of rabies virus by healthy vampire bats. Epidemiol. Infect. 133:517-522.

Alves L.M., Soares R.M., Cortez A., Richtzenhain L.J. \& Ito F.H. 2003. Pathogenesis of rabies virus by ERA and PV strains administered orally in hamsters (M. auratus). Braz. J. Vet. Res. Anim. Sci. 40:79-84.

Bourhy H., Kissi B., Lafon M., Sacramento D. \& Tordo N. 1992. Antigenic and molecular characterization of bat rabies virus in Europe. J. Clin. Microbiol. 30:2419-2426.

Brookes S.M., Klopfleisch R., Müller T., Healy D.M., Teifke J.P., Lange E., Kliemt J., Johnson N., Johnson L., Kaden V., Vos A. \& Fooks A. R. 2007. Susceptibility of sheep to European Bat Lyssavirus type-1 and -2 infection: a clinical pathogenesis study. Vet. Microbiol. 125:210-223.

Carnieli Jr. P., Ventura A.M. \& Durigon E.L. 2006. Digoxigenin-labeled probe for rabies virus nucleoprotein gene detection. Revta Soc. Bras. Med. Trop. 39:159-162.

Charlton K.M., Casey G.A. \& Webster W.A. 1984. Rabies virus in the salivary glands and nasal mucosa of naturally infected skunks. Can. J. Comp. Med. 48:338-339.

Constantine D.G. 1962. Rabies transmission by non-bite route. Publ. Health Rep. 77:287-289.

Constantine D.G., Emmons R.W. \& Woodie J.D. 1973. Rabies virus in nasal mucosa of naturally infected bats. Science 175:1255-1256.

Davis A.D., Rudd R.J. \& Bowen R.A. 2007. Effects of aerosolized rabies virus exposure on bats and mice. J. Infect. Dis. 195:1144-50.
Dean D.J., Abelseth M.K. \& Atanasiu P. 1996. The fluorescent antibody test, p.88-95. In: Meslin F.X., Kaplan M.M. \& Koprowski H. (Eds), Laboratory Techniques in Rabies. WHO, Genève.

Debbie J.G. \& Trimarchi C.V. 1970. Pantropism of rabies virus in free ranging rabid red foxes. J. Wildlife Dis. 6:500-506.

Echevarría J.E., Avellón A., Juste J., Vera M. \& Ibán C. 2001. Screening of active lyssavirus infection in wild bat populations by viral RNA detection on oropharyngeal swabs. J. Clin. Microbiol. 39:3678-3683.

Germano P.M.L., Miguel O., Ishizuka M.M. \& Silva E.V. 1988. Avaliação de três cepas de vírus da raiva, antigenicamente distintas, em camundongos. II - Estudo da disseminação viral, por diferentes órgãos. Revta Saúde Pública 22:473-478.

Hsu Y.H., Wang L.S., Chen L.K., Lee J.J. \& Yang H.H. 2005. Rabies Virus Infection: Report of an Autopsy Case with Comprehensive Pathologic, Immunofluorescent, Immunohistochemical and Molecular Studies. Tzu. Chin. Med. J. 18:219-225.

Jackson A.C. 2006. Rabies: New insights into pathogenesis and treatment. Curr. Opin. Neurol. 19:267-270.

Jogai S., Radotra B.D. \& Banerjee A.K. 2002. Rabies viral antigen in extracranial organs: a post-mortem study. Neuropathol. Appl. Neurobiol. 28:334-338.

Johnson N., Phillpotts R. \& Fooks A.R. 2006. Airborne transmission of lyssaviruses. J. Med. Microbiol. 55:785-790.

Li Z., Feng F. \& Ye H. 1995. Rabies viral antigen in human tongues and salivary glands. J. Trop. Med. Hyg. 98:330-332.

Lyles D.S. \& Rupprecht C.E. 2007. Rhabdoviridae, p.1385. In: Knipe D.M. \& Howley P.M. (Eds), Fields Virology. $5^{\text {th }}$ ed. [S.I.]: Lippincott Williams and Wilkins, Philadelphia.

Madhusudana S.N. \& Sukumaran S.M. 2008. Antemortem diagnosis and prevention of human rabies. Ann Indian Acad. Neurol. 11:3-12

MAPA 2007. Situação epidemiológica da raiva em herbívoros e suínos no período de 1996 a 2006. Ministério da Agricultura, Pecuária e Abastecimento. Available at <http://www.agricultura.gov.br/pls/portal/ docs/page/mapa/programas/area_animal/crhe/ppncr/n\%20de $\% 20$ casos\%20de\%20raiva\%20tabela\%201996-2006\%20-\%2013\%20de $\%$ 20agosto\%202007_0.pdf> Accessed on April 20, 2010.

Orciari L.A., Niezgoda M., Hanlon C.A., Shaddock J.H., Sanderlin D.W., Yager P.A. \& Rupprecht C.E. 2001. Rapid clearance of SAG-2 rabies virus from dogs after oral vaccination. Vaccine 19:4511-4518.

Ramsden R.O. \& Johnston D.H. 1975. Studies on the oral infectivity of rabies virus in Carnivora. J. Wildl. Dis. 11:318-324.

Scheffer K.C., Carrieri M.L., Albas A., Santos H.P.C., Kotait I. \& Ito F.H. 2007. Rabies virus in naturally infected bats in the state of São Paulo, southeastern Brazil. Revta Saúde Pública 41:389-395.

SVS 2008. Casos de raiva humana por espécie agressora, Brasil, 19862008. Secretaria de Vigilância em Saúde. http://www.saude.pr.gov.br /arquivos/File/zoonoses_intoxicacoes/raiva/serie_historica_da_raiva_ humana_por_especie_agressora_1986_2008.pdf

Superti F., Derer M. \& Tsiang H. 1984. Mechanism of rabies virus entry into CER cells. J. Gen. Virol. 65:781-789.

Webster W.A. \& Casey G.A. 1996. Virus isolation in neuroblastoma cell culture, p.96-104. In: Meslin F.X., Kaplan M.M. \& Koprowski H. (Eds), Laboratory Techniques in Rabies. WHO, Genève.

Winkler W.G. 1968. Airborne rabies virus isolation. Bull. Wildlife Disease Assoc. 4:37-40. 